\title{
Factors Influencing Interest in Continuing Higher Education to the Sekolah Tinggi Teologi Pelita Kebenaran Medan with Religiosity as Moderating Variables (Empirical Study of the Congregation Gereja Bethel Indonesia, Medan Plaza)
}

\author{
$\mathrm{Li} \mathrm{Ni}^{1}$, Galumbang Hutagalung ${ }^{2}$ \\ ${ }^{1,2}$ Universitas Prima Indonesia \\ Corresponding Author: Galumbang Hutagalung
}

\begin{abstract}
This study aims to determine the factors influencing interest in continuing higher education to the Sekolah Tinggi Teologi Pelita Kebenaran Medan with religiosity as moderating variables, empirical study of the Congregation Gereja Bethel Indonesia, Medan Plaza. This research is a type of causal comparative research. The sample of this study amounted to 108 respondents with the sampling method using simple random sampling, the data testing method used was the structural equation modeling (SEM) test. Based on the test results, it was found that attitude had a significant positive effect on interest, subjective norms did not have a significant effect on interest, perceived behavioral control did not have a significant effect on interest, religiosity was not proven to moderate the effect of attitude on interest, religiosity was proven to moderate the effect of subjective norms on interest, and religiosity was not proven to moderate the effect of perceived behavioral control on interest.
\end{abstract}

Keywords: Attitude, Subjective Norms, Perceived Behavioral Control, Religiosity, Interest

\section{INTRODUCTION}

Education has a very central and strategic role, especially if it is associated with efforts to improve the quality of human resources. This is because only qualified human resources will create an increase in true human dignity and worth. Higher education as one of the important parts in the world of education that is responsible for efforts to educate the nation's life has a very strategic responsibility and role to take part in overcoming problems of the quality of human resources.

Sekolah Tinggi Teologi (STT) Pelita Kebenaran is one of the private universities in the field of christian religion located in Medan which was established in 2011. STT was founded by the Gereja Bethel Indonesia (GBI) which aims to prepare God's ministers who will serve in church and society.

Based on preliminary research conducted by researchers by conducting informal talks with functionaries and campus employees, the authors received information that the decline in the number of students in 2017 was due to the declining interest of youth at GBI Medan to become God's servants who serve in the church and society. So that the management of GBI Medan made various efforts to increase the interest of young people in the GBI church to become servants of God by equipping themselves to study at STT Pelita Kebenaran. The result is that in 2018 there were 4 additional students and in 2019 there were 13 additions from 2018. This trend of decreasing and increasing students attracts 
Li Ni et.al. Factors influencing interest in continuing higher education to the Sekolah Tinggi Teologi Pelita Kebenaran Medan with religiosity as moderating variables (empirical study of the Congregation Gereja Bethel Indonesia, Medan Plaza).

the author's desire to examine what factors influence interest in continuing their studies at STT Pelita Kebenaran among students. youth members of the GBI Medan church.

Several studies on attitudes such as the research of Huda et al. (2012) found that attitudes, subjective norms and behavioral control have a significant influence on interest in choosing to pay zakat. Likewise, research by Norazlan et al. (2014) concluded that attitudes, subjective norms and behavioral control have a significant influence on voting interest.

However, the results of these studies contradict the research conducted by other researchers. Like the research of Suryani (2017) which found that Perceived Behavioral Control had no significant effect on taxpayer intentions. The results of this study were also supported by Wibowo (2016) who found that Perceptual Behavior Control had no significant effect on buying interest in private brand Alfamart products. Likewise with the Attitude variable, where in his research Dirgantara (2017) found that attitude had no effect on buying interest in green products. Likewise with the subjective norm variable, where research by Idris and Kasmo (2017) states that subjective norms have no significant effect on interest. The results of this study are supported by the research of Ningtyas et al. (2021) who found that subjective norms had no significant effect on interest.

The differences in research results as described above, made the researchers add a moderating variable. As explained by Govindarajan (1986) that differences in research results can be resolved through a contingency approach. So that in this study the author uses the variable religiosity as a moderating variable.

This study aims to determine the factors influencing interest in continuing higher education to the Sekolah Tinggi Teologi Pelita Kebenaran Medan with religiosity as moderating variables, empirical study of the Congregation Gereja Bethel Indonesia, Medan Plaza.

\section{LITERATURE REVIEW}

Interest in Continuing Higher Education

Interest can be interpreted as a tendency and high excitement or a great desire for something (Syah, 2011). Another definition states that interest is defined as a condition that occurs when a person sees the characteristics or temporary meaning of a situation that is associated with his own desires or needs (Sardiman, 2011).

Thus it can be concluded that a person's interest in continuing their education to college is a tendency that contains elements of feelings of pleasure, attention, interest, desire, need, drive and will.

Factors that influence the growth and development of interest are: (1) motivation and ideals, the existence of ideals and support by strong motivation within a person, it can raise parents' interest in something the object; (2) attitude towards an object, a happy attitude towards the object can be increase a person's interest in the object. On the other hand, if the attitude displeasure will diminish one's interest; (3) family is people the closest person to someone who usually always gives deep attention to that person. One of them is by giving awards for success a member of his family; (4)facilities, the availability of supporting facilities will make a person's interest in an object greater; (5)friends association, supportive friends, for example, are invited to compromise on something that attracts his attention then the friend can improve interest (Ahmadi, 2007).

Based on these aspects, it can be concluded that there are several indicators used in researching interest in continuing their studies to higher education, including: (1) willingness; (2) ideals; (3) needs; (4) desire and motivation.

\section{Attitude}

According to Azwar (2010) attitude is defined as a reaction or response that arises from an individual to an object which then gives rise to individual behavior towards the object in certain ways. 
Li Ni et.al. Factors influencing interest in continuing higher education to the Sekolah Tinggi Teologi Pelita Kebenaran Medan with religiosity as moderating variables (empirical study of the Congregation Gereja Bethel Indonesia, Medan Plaza).

Meanwhile, Gerungan (2004) describes the notion of attitude or attitude as a reaction to the views or feelings of an individual towards a particular object. The notion of attitude is also conveyed by Sarlito and Eko (2009), attitude is a process of assessment carried out by an individual towards an object. Objects that are addressed by individuals can be objects, people or information. Based on several expert opinions regarding attitudes, it can be concluded that attitude is a reaction or response in the form of an assessment that arises from an individual towards an object.

The attitude model towards an object or Fishbein model says that there are three main factors that predict attitudes (Mowen and Michael, 2001), namely:

1. The main belief that a person has towards an object means that belief is activated in memory when attention is focused on an object. Primary beliefs usually pay attention to attributes that are important to consumers.

2. The strength of the belief that the object has the attribute in question. This can be assessed with questions such as, how much confidence is object $\mathrm{x}$ has attribute $\mathrm{y}$.

3. Assessing or evaluating the main attributes of this assessment gives a bad rating on whether or not the main attribute or object.

Based on these aspects, it can be concluded that there are several indicators that are used in researching behavioral attitudes to continue their studies to higher education, including: (1) believing; (2) the right choice; (3) service; (4) promotion.

\section{Subjective Norms}

Subjective norms refer to the extent to which the relevant person or individual supports or does not support the performance of a particular behavior. In research, subjective norms are usually measured by asking participants to what extent they think their closest people family members, friends, or colleagues will support them in engaging in entrepreneurial activities (Linan and Chen, 2009). Usually, the more individuals perceive that their social referents support them to perform a behavior, the more individuals will tend to feel social pressure to elicit this behavior. And conversely, the more individuals perceive that their social referents do not approve of a behavior, the individuals tend to feel social pressure not to perform the behavior.

According to Anggelina and Japarianto (2014) this subjective norm is formed on the basis of the following indicators:

1. Normative Belief: is the belief in other people (preferred reference group) that they should or should not perform a behavior. Or normative beliefs about the expectations of others about what he should do. According to (Saeroji et al., 2015) this normative belief is a belief held by an individual that the environment and the people around him support what he does. Individual to perform a behavior based on the people closest to him (preferred group) and also because the surrounding environment has an influence on what decisions will be made by an individual.

2. Motivation to Comply: is a person's motivation to fulfill the expectations of those around him. This explains that the motivation to comply is a motivation that is in line with normative beliefs or it can be said that this subjective norm is a motivation that is in line with other people who are the reference group.

Based on these aspects, it can be concluded that there are several indicators that are used in examining subjective norms related to behavior to continue their studies to higher education, including: (1) family environment; (2) church environment.

\section{Perceived Behavioral Control}

According to Jogiyanto (2008), perceived behavioral control is the ease or difficulty of performing a behavior. Meanwhile, Azwar (1995) suggests that perceived behavioral control is determined 
Li Ni et.al. Factors influencing interest in continuing higher education to the Sekolah Tinggi Teologi Pelita Kebenaran Medan with religiosity as moderating variables (empirical study of the Congregation Gereja Bethel Indonesia, Medan Plaza).

by past experience and individual estimates of how difficult or easy it is to perform the behavior in question. Furthermore, Ajzen et al. (2009) explained that the more individuals perceive many supporting factors and fewer inhibiting factors to be able to perform a behavior, the greater the control they feel over the behavior and vice versa, the less individuals feel the supporting factors and many inhibiting factors to be able to perform a behavior. behavior, then individuals will tend to perceive themselves as difficult to perform the behavior.

From some of the definitions and descriptions above, the author can conclude that perceived behavioral control is an individual's perception of the control that the individual has in relation to certain behaviors which are beliefs about the presence or absence of factors that facilitate and prevent individuals from performing a behavior.

According to Ajzen (2009), there are 2 indicators of perceived behavioral control, namely:

1. Control beliefs, are beliefs about the resources and opportunities needed (requisite resources and opportunities) to elicit behavior.

2. Perceived power, is the behavior of the individual's perception of how strong the control is to influence himself in eliciting behavior so as to facilitate or complicate the appearance of the behavior.

Based on these aspects, it can be concluded that there are several indicators that are used in examining perceived behavioral control related to behavior to continue their studies to higher education, including: (1)desire to be a servant of God; (2)hospitality; (3)belief.

\section{Religiosity}

According to Gazalba in (Ghufron, 2012) religiosity comes from the word religion in Latin "religio" whose root word is religure which means binding. Thus, it implies that religion or religion in general has rules and obligations that must be obeyed and carried out by its adherents. All of them function to bind a person or group of people in relation to God, fellow human beings, and the natural surroundings. Meanwhile, Ancok and Suroso (2001) define religiosity as diversity which means covering various aspects or dimensions that not only occurs when a person performs ritual behavior (worship), but also performs other activities driven by supernatural powers.

Based on the explanation described above, it can be concluded that religiosity is a binding relationship between humans and God who is worshiped according to their religion, which makes humans have absolute dependence on all their needs, both physical needs and spiritual needs, which is implemented by directing heart, mind and feeling to always carry out religious teachings.

Indicators of religiosity according to Rahman et al. (2015) are as follows:

\section{Religious Believe}

Every religion has beliefs whose main role is to guarantee the existence of the divine and to define its character. In Islam it is the same as believing in the 5 pillars of faith, accepting this belief, in essence, accepting existence not only from God but from a personal God. Distinguished from guaranteed beliefs are beliefs that explain divine purposes and define human roles in relation to those goals.

\section{Religious Commitment}

That religiosity is defined as the extent to which a person is committed to his religion and how his religion is reflected in the individual's attitudes and behavior in everyday life.

Based on these aspects, it can be concluded that there are several indicators that are used in researching religiosity related to behavior to continue studies at university, including: (1) belief in the wisdom of God; (2) ecclesiastical ministry; (3) faith in prayer; (4) belief in an allknowing God. 
Li Ni et.al. Factors influencing interest in continuing higher education to the Sekolah Tinggi Teologi Pelita Kebenaran Medan with religiosity as moderating variables (empirical study of the Congregation Gereja Bethel Indonesia, Medan Plaza).

\section{RESEARCH METHODS}

The implementation of this research was carried out from April to July 2021 at the Gereja Bethel Indonesia, the Rumah Persembahan Medan Congregation.

This research is a type of causal comparative research, namely research that aims to investigate possible causal relationships by using a quantitative approach to test the established hypothesis (Sugiyono, 2011).

The population of this study is young people who are registered as church members at the Gereja Bethel Indonesia, the Rumah Persembahan Medan Congregation. According Pandiangan et al. (2018) in Sugiyono, purposive sampling is the selection of samples based on certain characteristics that are considered to have relevance to the characteristics of the population that have been known previously. Based on data obtained from the administrators of the Gereja Bethel Indonesia, the Rumah Persembahan Medan Congregation, there were 125 people. Library research is a form of research that uses library facilities by examining theoretical discussions from various books, articles, and scientific works related to writing (Pandiangan, 2018).

In this study the authors used a research sample based on what was suggested by Ghozali and Fuad (2005). Where they suggest to analyze the data using the structural equation model (SEM) the sample size is calculated using the formula 6 (six) times the number of indicators. There are 18 indicators in this study, so the minimum sample for SEM analysis is $18 \times 6=108$. Thus, the number of samples used in this study is at least 108 people.

Sampling technique is a way to determine the number of samples in accordance with the sample size that will be used as the actual data source, taking into account the characteristics and distribution of the population in order to obtain a representative sample. In this research, the sampling technique used is simple random sampling. The sampling technique using this method provides equal opportunities for each member of the population to become the research sample.

The study was conducted at a certain time (cross sectional) which reflects the phenomenon of a situation at some point in 2021. The variable measurement scale used in this study is the likert scale. To test the models and hypotheses, partial least square structural equation modeling (PLS-SEM) analysis was used, this study used SmartPLS, hypothesis testing was carried out using the bootstrapping method.

\section{RESULT AND DISCUSSION Profile}

Sekolah Tinggi Teologi (STT) is a higher education institution that is different from general higher education institutions. In this case, STT aims to prepare Christians who have a longing to serve God, both in church and in society. In particular, the STT is designed for those who want to be fulltime servants of God and for lay Christians who want to be equipped with a good knowledge of theology. Sekolah Tinggi Teologi (STT) Pelita Kebenaran is one of the private universities in the field of Christian religion located in Medan which was established in 2011. STT was founded by the Gereja Bethel Indonesia (GBI) which aims to prepare God's ministers who will serve in church and society.

\section{Hypothesis Test Results}

From the results of data processing, the results of the research hypotheses can be summarized as presented in Table 1.

\begin{tabular}{|c|c|c|c|c|}
\hline \multicolumn{2}{|c|}{ Hypothesis } & \multirow{2}{*}{$\begin{array}{c}\text { Coefficient of Effect } \\
0.194\end{array}$} & \multirow{2}{*}{$\begin{array}{c}\text { P Values } \\
0.182\end{array}$} & \multirow{2}{*}{$\begin{array}{c}\text { Decision } \\
\text { Not Accepted }\end{array}$} \\
\hline $\mathrm{H}_{1}$ & Attitude has a significant effect on interest. & & & \\
\hline $\mathrm{H}_{2}$ & Subjective Norms has a significant effect on interest. & 0.299 & 0.050 & Accepted \\
\hline $\mathrm{H}_{3}$ & Perceived behavior control has a significant effect on interest. & -0.318 & 0.042 & Accepted \\
\hline $\mathrm{H}_{4}$ & Religiosity moderates the effect of attitude on interest. & 0.046 & 0.758 & Not Accepted \\
\hline $\mathrm{H}_{5}$ & Religiosity moderates the effect of subjective norms on interest. & 0.250 & 0.108 & Not Accepted \\
\hline $\mathrm{H}_{6}$ & Religiosity moderates the effect of perceived behavior control on interest. & -0.294 & 0.020 & Accepted \\
\hline
\end{tabular}


Li Ni et.al. Factors influencing interest in continuing higher education to the Sekolah Tinggi Teologi Pelita Kebenaran Medan with religiosity as moderating variables (empirical study of the Congregation Gereja Bethel Indonesia, Medan Plaza).

Based on the test results, it was found that attitude had a significant positive effect on interest, subjective norms did not have a significant effect on interest, perceived behavioral control did not have a significant effect on interest, religiosity was not proven to moderate the effect of attitude on interest, religiosity was proven to moderate the effect of subjective norms on interest, and religiosity was not proven to moderate the effect of perceived behavioral control on interest.

\section{Coefficient of Determination Test (R2)}

The coefficient of determination test is carried out to see the amount of variance that can be explained by the independent variable on the dependent variable. The difference in the coefficient of determination of the value 1 shows the magnitude of the influence of other variables in explaining the variance in the dependent variable. The higher the value of $\mathrm{R} 2$, the greater the ability of the independent latent variable to explain the dependent latent variable. The results of R2 of 0.67 , 0.33 , and 0.19 indicate a "good", "moderate", and "weak" model (Ghozali, 2014). The calculation results obtained the value of R2 from the Mediation Variable and Dependent Variable shown in Table 2.

Table 2. Coefficient of Determination

\begin{tabular}{|l|c|c|}
\hline & R Square & R Square Adjusted \\
\hline Interest & 0.689 & 0.667 \\
\hline
\end{tabular}

From the results in Table 2, it can be concluded that the factors studied in this study can explain the interest in continuing higher education to the Sekolah Tinggi Teologi Pelita Kebenaran Medan of the Congregation Gereja Bethel Indonesia, Medan Plaza, which is $68.9 \%$, and the remaining $31.1 \%$ is explained by other factors.

\section{DISCUSSION}

\section{Attitude has a Positive Effect on Interest in Continuing at STT Pelita Kebenaran}

The results of statistical tests show that attitudes have a positive but not significant effect on the interest in continuing their studies at STT Pelita Kebenaran. This shows that the respondents do not yet have the behavior that makes them believe and trust to continue their studies to universities at STT Pelita Kebenaran. This can be seen from the respondents' answers to the entire question item about the attitude variable. Where from all respondents' answers are still in the high category. The statement "I believe the study program offered by STT Pelita Kebenaran is better than other STT study programs" is the lowest answer of all questions regarding the attitude of the respondents. This means that respondents are not so sure that STT Pelita Kebenaran is better than other STT study programs. The attitude of these respondents can be said as a manifestation of the stimulus they received from the manager of STT Pelita Kebenaran that they can become good servants of God in the Indonesian Bethel Church environment by continuing their studies at STT Pelita Kebenaran. The assessment that emerged was positive as a form of information they received about the state of STT Pelita Kebenaran and gave rise to a reaction in the form of an attitude that did not fully support their interest in continuing their higher education at STT Pelita Kebenaran, Medan.

\section{Subjective Norms has a Positive Effect on Interest in Continuing at STT Pelita Kebenaran}

The results of statistical testing show that subjective norms have a significant positive effect on interest in continuing their studies at STT Pelita Kebenaran. These results are in accordance with the respondents' answers, where there are $72.84 \%$ of respondents who choose the answer strongly agree and the answer agrees, which means that the subjective norm of the respondents in this study is in the good category. Thus, this explains why the results of statistical tests show that subjective norms have an effect on interest in continuing their studies at STT Pelita Kebenaran. 
Li Ni et.al. Factors influencing interest in continuing higher education to the Sekolah Tinggi Teologi Pelita Kebenaran Medan with religiosity as moderating variables (empirical study of the Congregation Gereja Bethel Indonesia, Medan Plaza).

Perceived Behavioral Control has a Negative Effect on Interest in Continuing at STT Pelita Kebenaran

The results of statistical tests show that the perceived behavior variable has a significant influence on the interest in continuing their studies to college. This can be explained based on the theory which states that broadly perceived behavioral control is influenced by factors from within the person himself and factors from outside himself (Ghufron and Risnawita 2016). Where the internal factors that contribute to self-control is age. The older a person gets, the better a person's ability to control himself to do or not do something. While external factors include the family environment, the family environment, especially parents, is an important factor in terms of self-control. It can be further explained that because the majority of the respondents in this study are relatively young (16-18 years old), based on the opinion of Ghufron and Risnawita (2016), their ability to control themselves to continue their studies at STT Pelita Kebenaran is relatively high. Likewise, their family environment is relatively high. support because the decision to continue studying is on them, so this can cause their perceived behavioral control ability to be good.

\section{Religiosity Moderates Attitude to Interest in Continuing at STT Pelita Kebenaran}

The results of statistical tests show that religiosity cannot moderate the influence of attitudes on interest in continuing their studies at STT Pelita Kebenaran. Based on the results of the previous test, it is known that the direct influence of attitude is significant but not significant on the interest in continuing the study, and it is hoped that with the interaction of the religiosity variable the influence will be stronger. But the fact that the test shows the interaction of the religiosity variable is not proven to weaken or strengthen the influence of attitude on the interest in continuing studies at STT Pelita Kebenaran.

\section{Religiosity Moderates Subjective Norms to Interest in Continuing at STT Pelita Kebenaran}

The results of statistical testing are able to show that religiosity is not proven to moderate the influence of subjective norms on the interest in continuing their studies to college at STT Pelita Kebenaran. Where the results of testing the direct hypothesis (without moderating) previously showed that subjective norms had a significant positive effect on interest in continuing their studies at STT Pelita Kebenaran. Likewise, the data on the answers of respondents who answered the research instrument on the religiosity variable showed $59.92 \%$ of respondents chose the answer strongly agree and the answer agreed where the percentage was close to an assessment score between 69 to 70 which means religiosity is almost in the pretty good category.

\section{Religiosity Moderates Perceived Behavior Control to Interest in Continuing at STT Pelita Kebenaran}

The results of statistical testing show that religiosity can moderate the effect of perceived behavioral control on interest in continuing studies at STT Pelita Kebenaran. As has been explained that the answers of respondents who answered the research instrument on the religiosity variable showed $59.92 \%$ of respondents chose the answer strongly agree and the answer agreed where the percentage was close to an assessment score between 69 to 70 which means religiosity is almost in the pretty good category. Of the total respondents' answers, there are $81.48 \%$ of respondents who chose the answer strongly agree and the answer agrees where the percentage is between the assessment scores between 80 to 100 . This means that the perceived behavioral control of respondents is in the very good category. Even though the respondents' answers were very good for the perceived behavioral control variable, 
Li Ni et.al. Factors influencing interest in continuing higher education to the Sekolah Tinggi Teologi Pelita Kebenaran Medan with religiosity as moderating variables (empirical study of the Congregation Gereja Bethel Indonesia, Medan Plaza).

religiosity was still unable to moderate the effect of these variables on the interest in continuing their studies at STT Pelita Kebenaran.

\section{CONCLUSION AND SUGGESTION Conclusion}

Based on the test results, it was found that attitude had a significant positive effect on interest, subjective norms did not have a significant effect on interest, perceived behavioral control did not have a significant effect on interest, religiosity was not proven to moderate the effect of attitude on interest, religiosity was proven to moderate the effect of subjective norms on interest, and religiosity was not proven to moderate the effect of perceived behavioral control on interest.

\section{Suggestion}

\section{For the Gereja Bethel Indonesia}

In order to improve coaching and teaching to church youth to increase their interest in continuing their studies at STT Pelita Kebenaran so that they can become the next generation to become servants of God at STT Pelita Kebenaran.

\section{For Young People of the Gereja Bethel Indonesia}

In order to further increase the interaction not only with the family environment, the church environment but also with the social environment in which they are located.

\section{For Other Researchers}

It is suggested to other researchers to use the religiosity variable as a mediating variable. So hopefully it will give different results.

\section{Acknowledgement: None}

\section{Conflict of Interest: None}

\section{Source of Funding: None}

\section{REFERENCES}

1. Abu Ahmadi (2007). Psikologi Sosial. Jakarta: Rineka Cipta.
2. Ajzen, Icek., Cornelia Czasch., \& Michael G. Flood (2009). From Intentions to Behavior: Implementation Intention, Commitment, and Conscientiousness. Journal of Applied Social Psychology, Volume39, Issue 6.

3. Anggelina J.P \& Edwin Japarianto (2014). Analisa Pengaruh Sikap, Subjective Norm dan Perceived Behavioral Control terhadap Purchase Intention Pelanggan SOGO Departement Store di Tunjungan Plaza Surabaya, Jurnal Strategi Pemasaran Vol 2, No.1, (2014) 1-7.

4. Azwar, Saifudin (1995). Sikap Manusia: Teori dan Pengukurannya Edisi Kedua.Yogyakarta: Pustaka Pelajar Offset.

5. (2010). Sikap Manusia, Teori dan Pengukurannya. Yogyakarta: Liberty.

6. Dirgantara, Oviean Dicky (2017). Pengaruh Pengetahuan, Kepedulian, dan Sikap Terhadap Minat Beli Produk Hijau Yang Dimoderasi oleh Perbedaan (Studi pada Konsumen Mobil Toyota LCGC Agya di D.I. Yogakarta). Fakultas Ekonomi dan Bisnis Universitas Muhammadiyah Yogyakarta.

7. Gerungan, W.A (2004). Psikologi Sosial, PT. Refika Aditama, IKAPI, Bandung.

8. Ghozali, Imam \& Fuad. 2005. Structural Equation Modeling: Teori, Konsep, dan Aplikasi. Semarang: Badan Penerbit Universitas Diponegoro.

9. Ghufron, N. M., \& Risnawita, R. (2016). Teori-teori psikologi. Jogjakarta: Ar-Ruzz Media.

10. Govindarajan, V. (1986). "Impact of Participation in the Budgetary Process on Managerial Attitudes and Performance: Universalisticand Contingency erspectives", Decision Sciences, 17, pp. 496-516.

11. Hasbullah, Norazlan et al. (2014). Extending the Theory of Planned Behavior: Evidence of the Arguments of its Sufficiency. International Journal of Humanities and Social Science, 4(14), 101105.

12. Idris Idris \& Arief Bowo Prayoga Kasmo (2017). Pengaruh Sikap, Norma Subjektif dan Persepsi Kontrol Perilaku Terhadap Minat Kepemilikan Kartu Kredit. Jurnal Manajemen dan Bisnis Indonesia 4(3):306.

13. Jogiyanto, H.M (2008). Sistem Informasi Keperilakuan. 2 ed. Yogyakarta: Andi.

14. Lilis, Suryani (2017) Pengaruh Sikap, Norma Subyektif dan Kontrol Perilaku 
Li Ni et.al. Factors influencing interest in continuing higher education to the Sekolah Tinggi Teologi Pelita Kebenaran Medan with religiosity as moderating variables (empirical study of the Congregation Gereja Bethel Indonesia, Medan Plaza).

Persepsian Terhadap Kepatuhan Wajin Pajak Orang Pribadi di Daerah Istimewa Yogyakarta Dengan Niat Mematuhi Pajak Sebagai Variabel Pemoderasi. Program Studi Akuntansi Fakultas Ekonomi Universitas Negeri Yogyakarta.

15. Linan, Francisco \& Yi-Wen Chen (2009). Development and Cross Cultural AppliationOf a Specific Instrument to Measure Entrpreneurial Intentions. Entrepreneurship: Theory and Practice, Vol. 33(3):593-617.

16. Mowen, John C \& Michael Minor. 2001. Perilaku Konsumen (Jilid 1) Edisi Kelima. Jakarta: Erlangga.

17. Nurul Huda, Nova Rini, Yosi Mardoni, Purnama Putra (2012). The Analysis of Attitudes, Subjective Norms, and Behavioral Control on Muzakki's Intention to Pay Zakah. International Journal of Business and Social Science Vol. 3 No. 22 [Special Issue - November 2012].

18. Ningtyas, Yunita., Dessy Fitria., Yolanda Sryta Pradani., Mutohar., Nisa Puspita Arum., \& Lu'luul Maknun (2021). Analisis Pengaruh Sikap, Norma Subyektif, dan Persepsi Kontrol Perilaku Terhadap Minat Beli Konsumen pada Produk Bersertifikat Halal. Intelektiva: Jurnal Ekonomi, Sosial \& Humaniora. Vol. 2 N0. 08 - Maret 2021.

19. Pandiangan, Saut Maruli Tua, Rujiman, Rahmanta, Tanjung, Indra I., Darus, Muhammad Dhio, \& Ismawan, Agus. (2018). An Analysis on the Factors which Influence Offering the Elderly as Workers in Medan. IOSR Journal of Humanities and Social Science (IOSR-JHSS), 23(10), 76-79.

20. Pandiangan, Saut Maruli Tua. (2018). Analisis Faktor-faktor yang Mempengaruhi Penawaran Tenaga Kerja Lanjut Usia di Kota Medan. Tesis. Medan: Fakultas
Ekonomi dan Bisnis, Program Studi Ilmu Ekonomi, Universitas Sumatera Utara. http://repositori.usu.ac.id/bitstream/handle/1 23456789/10033/167018013.pdf?sequence= 1 \&isAllowed=y.

21. Rahman, A., Ebrahim, A., \& Rahman, S. (2015). Consumers and Halal Cosmetic Products: Knowledge, Religiosity, Attitude, and Intention. Journal of Islamic Marketing. Bingley, Vol. 6, Issue 1 (2015), PP 148-163.

22. Sardiman, A.M (2011). Interaksi dan Motivasi Belajar Mengajar. Jakarta: Rajawali Press.

23. Sarwono, Sarlito W \& Eko A Meinarno (2009). Psikologi Sosial. Jakarta: Salemba Humanika.

24. Sugiyono (2011). Metode Penelitian Kuantitatif Kualitatif dan R \& B, Bandung: Alfabeta.

25. Syah, Muhibbin (2011). Psikologi Pendidikan dengan Pendekatan Baru. Bandung: Remaja Rosdakarya.

26. Wibowo, Amanda Anidia Ita. (2016). "Analisis Pengaruh Sikap, Norma Subyektif, Dan Kontrol Perilaku Yang Dirasakan Terhadap Minat Beli Produk Private Brand Alfamart Di Sekitar Universitas Muhammadiyah Surakarta," Skripsi Surakarta: Universitas Muhammadiyah Surakarta.

How to cite this article: Li Ni, Hutagalung G. Factors influencing interest in continuing higher education to the Sekolah Tinggi Teologi Pelita Kebenaran Medan with religiosity as moderating variables (empirical study of the Congregation Gereja Bethel Indonesia, Medan Plaza). International Journal of Research and Review. 2021; 8(8): 636-644. DOI: https://doi. org/10.52403/ijrr.20210884 